\title{
Extraskeletal Calcifications in Children with Maintenance Peritoneal Dialysis
}

\author{
Eunhye Oh, M.D. ${ }^{1}$ \\ Jeesu Min, M.D. ${ }^{1}$ \\ Seon Hee Lim, M.D. ${ }^{2}$ \\ Ji Hyun Kim, M.D. ${ }^{3}$ \\ II-Soo Ha, M.D., Ph.D. ${ }^{1,4,5}$ \\ Hee Gyung Kang, M.D., Ph.D. ${ }^{1,4,5,6}$ \\ Yo Han Ahn, M.D., Ph.D. ${ }^{1,4,5}$

\begin{abstract}
'Department of Pediatrics, Seoul National University Children's Hospital, Seoul, Republic of Korea, ${ }^{2}$ Department of Pediatrics, Uijeongbu Eulji Medical Center, Uijeongbu-si, Republic of Korea, ${ }^{3}$ Department of Pediatrics, Seoul National University Bundang Hospital, Seongnam, Republic of Korea, ${ }^{4}$ Department of Pediatrics, Seoul National University College of Medicine, Seoul, Republic of Korea, ${ }^{5}$ Kidney Research Institute, Seoul National University College of Medicine, Seoul, Republic of Korea, ${ }^{6}$ Wide River Institute of Immunology, Seoul National University,

Hongcheon, Republic of Korea

Corresponding author:

Yo Han Ahn, M.D., Ph.D.

Department of Pediatrics, Seoul National University Children's Hospital and College of Medicine, 101 Daehakro, Jongno-gu,

Seoul 03080, Republic of Korea

Tel: +82-2-2072-3350

Fax: +82-2-2072-0633
\end{abstract} \\ E-mail:yhahn@snu.ac.kr
}

Received: 25 August 2021

Revised: 5 October 2021

Accepted: 6 October 2021

This is an open-access article distributed under the terms of the Creative Commons Attribution Non-Commercial License (http:// creativecommons.org/licenses/by-nc/4.0/) which permits unrestricted non-commercial use, distribution, and reproduction in any medium, provided the original work is properly cited.

Copyright (C) 2021 The Korean Society of Pediatric Nephrology
Chronic kidney disease (CKD)-mineral and bone disorder (CKD-MBD) is a common complication of CKD, often accompanied by extra-skeletal calcification in adult patients. As increased vascular calcification is predicted to increase cardiovascular mortality and morbidity, the revised Kidney Disease: Improving Global Outcomes guidelines recommend avoiding calcium-containing phosphate chelators. However, extra-skeletal calcification is less commonly noticed in pediatric patients. Here, we report our experience of such a complication in pediatric patients receiving maintenance peritoneal dialysis. Extra-skeletal calcification was noticed at the corneas, pelvic cavity, and soft tissues of the lower leg in 4 out of 32 patients on maintenance peritoneal dialysis. These patients experienced the aggravation of extra-skeletal calcifications during peritoneal dialysis, and 2 of them underwent excisional operations. It is required to monitor extra-skeletal calcifications in children on kidney replacement therapy.

Key words: Chronic kidney disease-mineral and bone disorder, Pathologic calcification, Peritoneal dialysis

\section{Introduction}

Chronic kidney disease (CKD)-mineral and bone disorder (CKD-MBD), which is disturbed bone and mineral homeostasis leading to bone remodeling, is a common complication of $\mathrm{CKD}^{1)}$. Since the kidney plays a major role in bone and mineral homeostasis by regulating serum calcium and phosphorus levels, parathyroid hormone (PTH), and vitamin D metabolism²), failing kidneys result in the disturbance of these compounds. In addition to pathologic bone remodeling, extra-skeletal calcification often accompanies CKD-MBD. In adult patients with kidney failure with replacement therapy (KFRT), calcifications are present in up to $76 \%$ of patients ${ }^{3}$. Locations of calcification vary from the arteries to the periarticular regions to internal organs such as the lungs and heart, eyes, and skin ${ }^{4}$. The severity of calcification is also diverse, from simple calcification without any symptoms to calciphylaxis, which is calcific uremic arteriolopathy characterized by the occlusion of arterioles, resulting in ischemia and tissue necrosis. Depending on the location of calcifications, symptoms could be critical; those of coronary vessels, heart, and lungs may lead to death. Although extra-skeletal calcification is known to be less common in pediatric patients, its localization is similar to adults in 
reported cases ${ }^{5,6)}$. Because increased vascular calcification is predicted to increase cardiovascular mortality and morbidity, the revised Kidney Disease: Improving Global Outcomes (KDIGO) guidelines for CKD-MBD recommend maintaining a normal range of serum phosphate and calcium levels in CKD patients, avoiding calcium-containing phosphate chelators, and using a dialysate containing lower calcium ${ }^{7}$.

Although the significance of extra-skeletal calcification in adult patients with KFRT is well known, it is less commonly noticed in pediatric patients, and calcium-containing phosphate binders remain the first choice of treatment when hyperphosphatemia develops in patients with CKD. However, extra-skeletal calcification does occur in pediatric patients with KFRT. Here, we report our experience of extra-skeletal calcifications in pediatric patients receiving maintenance peritoneal dialysis (PD).

\section{Case report}

Of the 32 patients who were receiving PD in Seoul National University Children's Hospital in 2019, extra-skeletal calcification was found in 4 patients (12.5\%) (Table 1). The patients' ages at the time of diagnosis of calcification ranged from 8.1 to 21.3 years. The locations of calcifications were diverse, including the cornea, pelvic cavity, and soft tissues of the lower leg. The laboratory findings from the initial onset of CKD to the development of extra-skeletal calcification are shown in Table 2. All patients were taking phosphate binders, including calcium carbonate, whereas 2 patients took alfacalcidol to control their hyperparathyroidism.

Case 1 developed CKD due to hypoparathyroidism, sensorineural deafness, and renal disease (HDR) syndrome at the age of 4.9 years. She had corneal opacity, which was

Table 1. Characteristics of Patients with Extra-skeletal Calcifications

\begin{tabular}{|c|c|c|c|c|c|c|c|c|c|c|c|c|c|}
\hline \multirow[b]{2}{*}{ Case } & \multirow{2}{*}{$\begin{array}{l}\text { Sex/Age } \\
\text { (years) }\end{array}$} & \multirow{2}{*}{$\begin{array}{l}\text { Underlying } \\
\text { kidney disease }\end{array}$} & \multirow{2}{*}{$\begin{array}{c}\text { Age of } \\
\text { starting PD } \\
\text { (years) }\end{array}$} & \multirow[b]{2}{*}{ Location } & \multicolumn{7}{|c|}{ Laboratory findings at the diagnosis of calcification } & \multirow{2}{*}{$\begin{array}{l}\text { CKD-MBD } \\
\text { medication }\end{array}$} & \multirow{2}{*}{$\begin{array}{l}\text { Surgical } \\
\text { removal }\end{array}$} \\
\hline & & & & & $\begin{array}{c}\text { Corrected } \\
\mathrm{Ca}^{*}(\mathrm{mg} / \mathrm{dL})\end{array}$ & $\begin{array}{c}\mathrm{P} \\
(\mathrm{mg} / \mathrm{dL})\end{array}$ & $\begin{array}{l}\text { BUN/Cr } \\
(\mathrm{mg} / \mathrm{dL})\end{array}$ & $\begin{array}{c}\text { eGFR }(\mathrm{mL} / \\
\left.\mathrm{min} / 1.73 \mathrm{~m}^{2}\right)\end{array}$ & $\begin{array}{l}\text { ALP } \\
\text { (IU/L) }\end{array}$ & $\begin{array}{l}25(\mathrm{OH}) \mathrm{D} \\
(\mathrm{ng} / \mathrm{mL})\end{array}$ & $\begin{array}{c}\text { PTH } \\
(\mathrm{pg} / \mathrm{mL})\end{array}$ & & \\
\hline 1 & $F / 8.1$ & $\begin{array}{c}\text { C1q } \\
\text { nephropathy }\end{array}$ & 8.5 & Bilateral corneas & 7.8 & 4.1 & $31 / 1.86$ & 23.0 & 43 & 12.6 & $<5$ & $\begin{array}{l}\text { Alfacalcidol, } \\
\text { calcium } \\
\text { carbonate }\end{array}$ & Yes \\
\hline 2 & $M / 14.8$ & $\begin{array}{l}\text { Renal ischemic } \\
\text { injury }\end{array}$ & 12.7 & $\begin{array}{l}\text { Subcutaneous } \\
\text { tissue of bilateral } \\
\text { buttock to thigh }\end{array}$ & 10.4 & 3.8 & $28 / 6.21$ & 9.3 & 103 & 22.8 & 202 & $\begin{array}{l}\text { Sevelamer, } \\
\text { calcium } \\
\text { polystyrene } \\
\text { sulfonate }\end{array}$ & No \\
\hline 3 & M/17.9 & $\begin{array}{l}\text { FSGS caused } \\
\text { by a /NF2 } \\
\text { mutation }\end{array}$ & 17.9 & Pelvic cavity & 9.4 & 5.6 & $68 / 9.8$ & 7.5 & 55 & ND & 121.5 & $\begin{array}{l}\text { Alfacalcidol, } \\
\text { calcium } \\
\text { carbonate }\end{array}$ & No \\
\hline 4 & $M / 21.3$ & FSGS & 16.3 & $\begin{array}{l}\text { Subcutaneous } \\
\text { tissue of left pre- } \\
\text { tibial area }\end{array}$ & 9.9 & 5.7 & $70 / 25.8$ & 2.6 & 90 & ND & 209.5 & Sevelamer & Yes \\
\hline
\end{tabular}

Abbreviations: PD, peritoneal dialysis; Ca, calcium; P, phosphorus; BUN, blood urea nitrogen; Cr, creatinine; eGFR, estimated glomerular filtration rate; ALP, alkaline phosphatase; 25(OH)D, 25-hydroxyvitamin D; PTH, parathyroid hormone; F, female; M, male; FSGS, focal segmental glomerulosclerosis; ND, not done. ${ }^{*}$ Corrected calcium=serum total calcium $(\mathrm{mg} / \mathrm{dL})+0.8$ [4-serum albumin $\left.(\mathrm{g} / \mathrm{dL})\right]$.

Table 2. Laboratory Findings from Initial Onset of Chronic Kidney Disease to Development of Extra-skeletal Calcifications

\begin{tabular}{|c|c|c|c|c|c|c|c|c|}
\hline Case & $\begin{array}{l}\text { Mean corrected } \\
\mathrm{Ca}^{*}(\mathrm{mg} / \mathrm{dL})\end{array}$ & $\begin{array}{l}\text { Duration of } \\
\text { hypercalcemia }^{\dagger} \\
\text { (months/year) }^{\text {(mons }}\end{array}$ & $\begin{array}{l}\text { Mean P } \\
(\mathrm{mg} / \mathrm{dL})\end{array}$ & $\begin{array}{c}\text { Duration of } \\
\text { hyperphosphatemia } \\
\text { (months/year) }\end{array}$ & $\begin{array}{l}\text { Mean corrected } \\
\text { CaxP }\left(\mathrm{mg}^{2} / \mathrm{dL}^{2}\right)\end{array}$ & $\begin{array}{c}\text { Duration of } \\
\text { CaxP }>55 \mathrm{mg}^{2} / \mathrm{dL}^{2} \\
\text { (months/year) }\end{array}$ & $\begin{array}{c}\text { Mean PTH } \\
(\mathrm{pg} / \mathrm{mL})\end{array}$ & $\begin{array}{c}\text { Duration of } \\
\text { hyperparathyroidism } \\
\text { (months/year) }\end{array}$ \\
\hline 1 & $8.8 \pm 1.0$ & 0.5 & $5.5 \pm 1.5$ & 8.0 & $48.4 \pm 13.6$ & 6.7 & $17.6 \pm 5.4$ & 0 \\
\hline 2 & $10.4 \pm 0.7$ & 9.6 & $5.3 \pm 1.4$ & 7.9 & $55.3 \pm 15.7$ & 6.8 & $365.7 \pm 267.3$ & 4.0 \\
\hline 3 & $9.4 \pm 0.4$ & 0 & $4.5 \pm 0.8$ & 5.4 & $42.1 \pm 7.1$ & 0.3 & $129.4 \pm 97.3$ & 7.4 \\
\hline 4 & $9.7 \pm 0.3$ & 0.5 & $5.3 \pm 1.3$ & 8.3 & $51.2 \pm 12.8$ & 4.1 & $182.2 \pm 92.2$ & 1.0 \\
\hline
\end{tabular}

Abbreviations: Ca, calcium; P, phosphorus; BUN, blood urea nitrogen; $\mathrm{PTH}$, parathyroid hormone.

"Corrected calcium=serum total calcium (mg/dL)+0.8 [4-serum albumin ( $/ \mathrm{dL})$ ].

${ }^{+}$Hypercalcemia and hyperphosphatemia are defined as values greater than the upper limit of the reference range in serum calcium and phosphorus, respectively.

${ }^{\ddagger}$ Hyperparathyroidism is defined as serum parathyroid hormone $>70 \mathrm{pg} / \mathrm{mL}$ in chronic kidney disease stage (CKD) 3, >110 pg/mL in CKD stage 4, and $>300 \mathrm{pg} / \mathrm{mL}$ in CKD stage 5 . 
diagnosed as bilateral calcific band keratopathy, at the age of 8.1 years (Fig. 1A). PD was started at the age of 8.5 years. Two years after initiating dialysis, she underwent two ophthalmic surgeries due to aggravated calcification deposits on the bilateral corneas.

Case 2 has been bedridden since birth, requiring ventilation support due to birth asphyxia and resulting in multiple organ failure. His kidney function deteriorated probably due to repeated acute kidney injuries caused by infection, respiratory failure, and shock. He was diagnosed with CKD at the age of 11.4 years and started PD at the age of 12.7 years. In a span of 2 years, multiple calcifications on the subcutaneous tissues of the bilateral leg were found (Fig. 1B). To rule out any tumors, tissue biopsy was done, and the pathologic findings revealed fibroadipose tissue with dystrophic calcification (Fig. 2A).

Case 3 was diagnosed with focal segmental glomerulosclerosis (FSGS) caused by INF2 mutation at the age of 11.2 years. He started PD at the age of 17.9 years. At the time of dialysis initiation, he was incidentally found to have multiple calcifications in the area of the pelvic cavity (Fig. 1C). Although the calcifications increased in number and extent during dialysis, he had no symptoms associated with calcifications.

Case 4 was diagnosed with FSGS at the age of 8.6 years and progressed to CKD at the age of 11.2 years. His KFRT was initiated at the age of 16.3 years. At the age of 21.3 years, he complained of a growing palpable mass on the left lower leg (Fig. 1D), which was excised and diagnosed as fibroadipose tissue with dystrophic calcification (Fig. 2B).

\section{Discussion}

Calcification of vessels and soft tissues is one of the manifestations of CKD-MBD ${ }^{8)}$. Although vascular calcification of adults are often from atherosclerotic changes in elderly people, extra-skeletal calcifications, including vascular calcifications in adult patients with CKD, occur even in young patients, albeit with different mechanisms ${ }^{8)}$. Decline in kidney function, dialysis, and mineral imbalance could accelerate calcifications of patients with $\mathrm{CKD}^{9)}$. The risk factors for extra-skeletal calcifications include age, elevated calcium and phosphate product, hyperparathyroidism, high calcium dialysate, vitamin $\mathrm{D}$ supplements, and the use of aluminum hydroxyl as a phosphate binder. Similarly, in
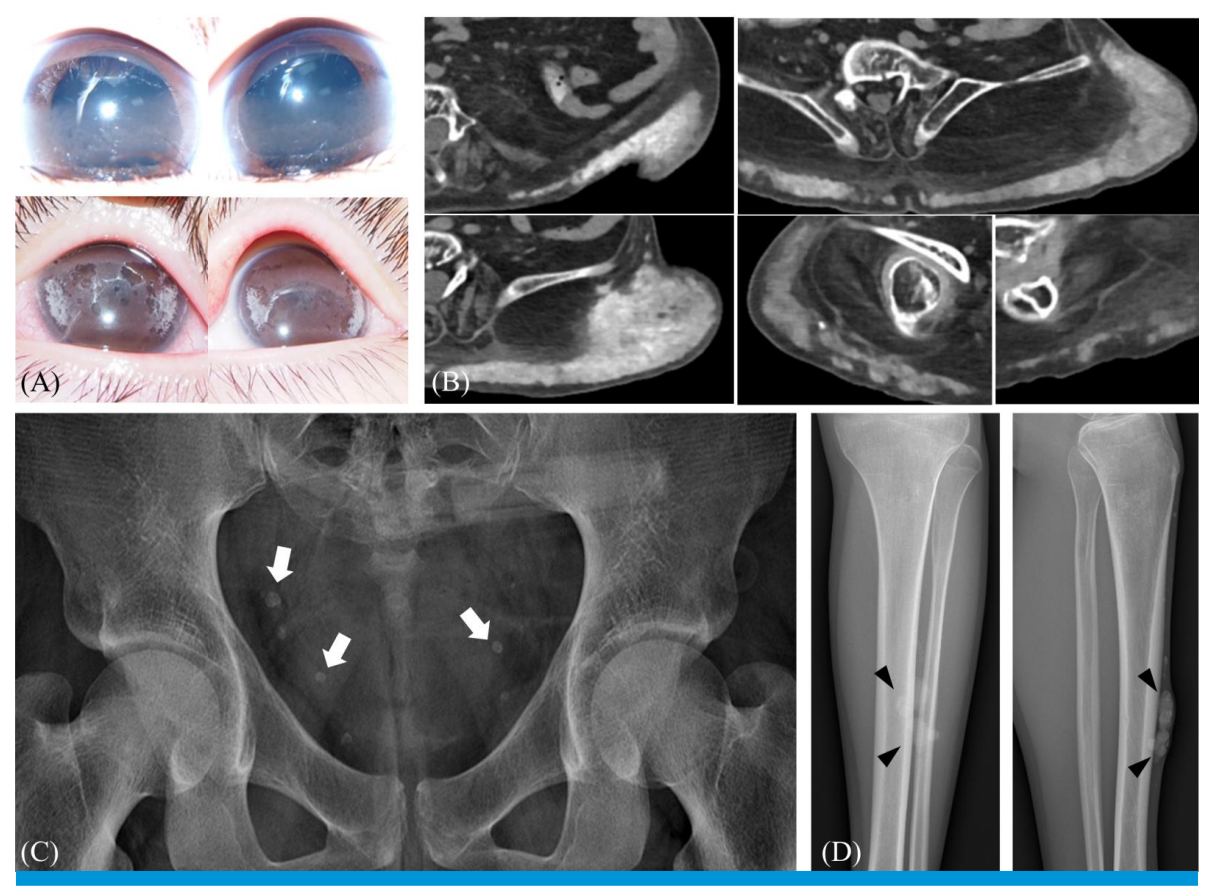

Fig. 1. Calcifications shown in patients. (A) Band keratopathy in the bilateral corneas (case 1) (B) Computerized tomography image of a palpable mass at the left flank and both hips (white arrows, case 2) (C) Incidentally found calcifications of the pelvic cavity (white arrows, case 3) (D) Palpable and slowly growing mass of the anterior tibial area (case 4). 


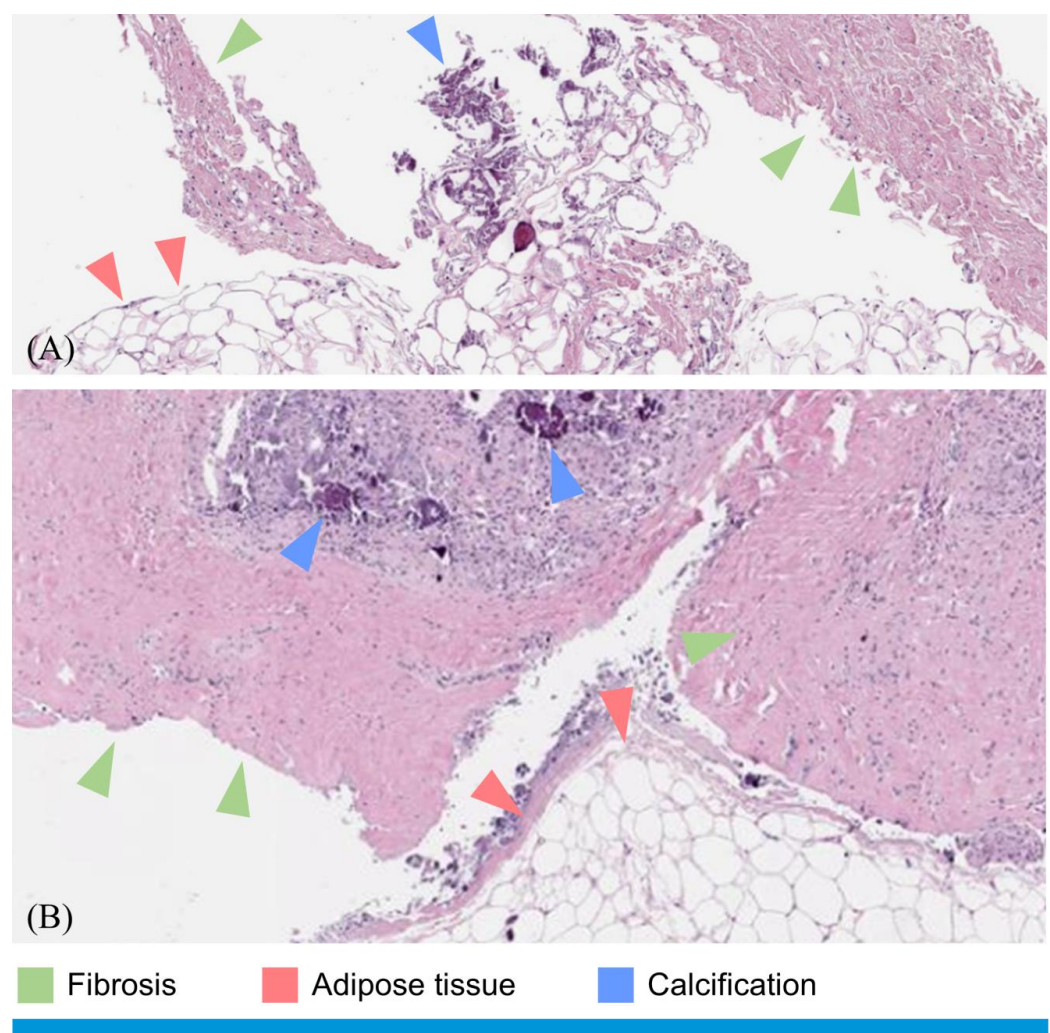

Fig. 2. Pathological slide of the palpable mass. Both slides show fibroadipose tissues with calcifications. (green arrowhead, fibrosis; red arrowhead, adipose tissue; blue arrowhead, calcification) (A) Specimen obtained by needle biopsy (case 2) (B) Specimen obtained by excision (case 4).

pediatric patients with KFRT, calcifications were reported to be associated with hypertension, elevated serum levels of PTH, calcium and phosphate product, and long-term dialysis ${ }^{4,6}$. In the cases discussed here, calcification occurred even before the initiation of dialysis in two patients. One patient was at risk for extra-skeletal calcification due to an underlying HDR syndrome, which is known to be associated with band keratopathy ${ }^{10)}$. Another patient with preKFRT extra-skeletal calcifications had a relatively long history of CKD, along with calcium carbonate intake of a long duration. The other two patients had low-extremity soft tissue calcifications 2 and 5 years after initiation of PD; one patient had a shorter duration of undergoing dialysis but had a long history of being bedridden, which might have contributed to bone resorption leading to unnoticed/ uncontrolled hypercalcemia. In addition, extra-skeletal calcifications of atypical areas in our cases could result from other causes including steroid-induced calciphylaxis in patients with FSGS and fat tissue necrosis in a bedridden patient.
Since the correlation between calcification and vessel thickness/stiffness has been revealed in pediatric KFRT on dialysis $^{7}$, extra-skeletal calcification also needs to be prevented and treated properly in pediatric patients. Calcifications in CKD can be managed using non-calcium-based phosphate binders to control hyperphosphatemia, calcimimetics to activate calcium-sensing receptors, and kidney transplantation ${ }^{11)}$. However, the aim of these methods is to prevent the aggravation of calcification, not to reverse the process $^{9}$. In our cases, band keratosis and solitary mass lesions were surgically removed; calcifications in the other cases could not be treated, but measures to prevent aggravation, as recommend in the literature, were introduced, such as controlling serum calcium and phosphate levels more strictly, targeting age-appropriate normal ranges for calcium and phosphorous product $<55 \mathrm{mg}^{2} / \mathrm{dL}^{2}$, switching calcium-containing phosphate binders to non-calciumcontaining ones such as sevelamer, and encouraging dietary restriction of phosphate ${ }^{3,7,12)}$. Although using dialysates of low-calcium concentrations ( 2.5 and $3.0 \mathrm{mEq} / \mathrm{L}$ ) are also 
recommended ${ }^{7,13)}$, their use might also be accompanied by side effects such as cardiac arrhythmia and muscle cramp; hence, we did not use low-calcium-containing dialysates unless hypercalcemia was present, as was the case with case 2 , which sometimes showed hypercalcemia that required use of low-calcium dialysate. Hyperparathyroidism should also be strictly controlled using adequate phosphate binders, vitamin D, calcimimetics such as cinacalcet, or even parathyroidectomy, ${ }^{3,714)}$.

Extra-skeletal calcifications in pediatric patients with KFRT are uncommon; however, they can develop due to variable causes. Since there are no definite treatments to completely resolve this complication, a stringent management of CKD-MBD is required to prevent occurrence and aggravation of calcifications. Pediatricians might also need to monitor the development of extra-skeletal calcifications in children with CKD.

\section{Patients consent}

This study was reviewed and approved by the Institutional Review Board (IRB) of Seoul National University Hospital (IRB No. 2004-137-1117). The requirement for informed consent was waived due to the retrospective nature of the study.

\section{Conflicts of interest}

No potential conflict of interest relevant to this article was reported.

\section{ORCID}

Eunhye Oh http://orcid.org/0000-0002-0108-5304

Jeesu Min http://orcid.org/0000-0003-1535-7769

Seon Hee Lim http://orcid.org/0000-0001-8327-7002

Ji Hyun Kim http://orcid.org/0000-0001-8477-0157

Il-Soo Ha http://orcid.org/0000-0001-5428-6209

Hee Gyung Kang http://orcid.org/0000-0001-8323-5320

Yo Han Ahn http://orcid.org/0000-0002-8185-4408

\section{References}

1. Suh JS. Diagnosis and Management of Chronic Kidney DiseaseMineral Bone Disease in Children. Childhood Kidney Diseases 2020;24:14-8.

2. Heaf JG. Chronic Kidney Disease-Mineral Bone Disorder in the Elderly Peritoneal Dialysis Patient. Perit Dial Int 2015;35:640-4.

3. Goel SK, Bellovich K, McCullough PA. Treatment of severe metastatic calcification and calciphylaxis in dialysis patients. Int J Nephrol 2011;2011:701603.

4. Drüeke TB. A clinical approach to the uraemic patient with extraskeletal calcifications. Nephrology Dialysis Transplantation 1996;11:37-42.

5. Milliner DS, Zinsmeister AR, Lieberman E, Landing B. Soft tissue calcification in pediatric patients with end-stage renal disease. Kidney Int 1990;38:931-6.

6. Sheth RD, Perez MD, Goldstein SL. Cardiovascular calcifications in pediatric patients receiving maintenance dialysis. Pediatr Nephrol 2003;18:810-3.

7. Kidney Disease: Improving Global Outcomes (KDIGO) CKD-MBD Update Work Group. KDIGO 2017 Clinical Practice Guideline Update for the Diagnosis, Evaluation, Prevention, and Treatment of Chronic Kidney Disease-Mineral and Bone Disorder (CKD-MBD). Kidney Int Suppl 2017;7:1-59.

8. Wesseling K, Bakkaloglu S, Salusky I. Chronic kidney disease mineral and bone disorder in children. Pediatr Nephrol 2008;23:195-207.

9. Palit S, Kendrick J. Vascular calcification in chronic kidney disease: role of disordered mineral metabolism. Curr Pharm Des 2014;20: 5829-33.

10. Kim C, Cheong HI, Kim JH, Yu YS, Kwon JW. Presumed atypical HDR syndrome associated with Band Keratopathy and pigmentary retinopathy. J Pediatr Ophthalmol Strabismus 2011;48 Online:e1-3.

11. Khouzam N, Wesseling-Perry K. Pathophysiology and treatment of cardiovascular disease in pediatric chronic kidney disease. Pediatr Nephrol 2019;34:1-10.

12. Fathallah-Shaykh S, Drozdz D, Flynn J, Jenkins R, Wesseling-Perry K, Swartz SJ, et al. Efficacy and safety of sevelamer carbonate in hyperphosphatemic pediatric patients with chronic kidney disease. Pediatr Nephrol 2018;33:325-33.

13. Toussaint N, Cooney P, Kerr PG. Review of dialysate calcium concentration in hemodialysis. Hemodial Int 2006;10:326-37.

14. Warady BA, lles JN, Ariceta G, Dehmel B, Hidalgo G, Jiang X, et al. A randomized, double-blind, placebo-controlled study to assess the efficacy and safety of cinacalcet in pediatric patients with chronic kidney disease and secondary hyperparathyroidism receiving dialysis. Pediatr Nephrol 2019;34:475-86. 